ORIENTAL JOURNAL OF CHEMISTRY

An International Open Free Access, Peer Reviewed Research Journal

www.orientjchem.org
ISSN: 0970-020 X

CODEN: OJCHEG

2014, Vol. 30, No. (2):

Pg. 435-443

\title{
Microwave-Assisted Synthesis of Potent Antimicrobial Agents of Flavanone Derivatives
}

\author{
ABDULLAH S. AL-BOGAMI ${ }^{1 *}$, HAMAD Z. ALKHATHLAN², \\ TAMER S. SALEH ${ }^{1}$ and AHMED M. ELAZZAZY ${ }^{3}$ \\ ${ }^{1}$ Department of Chemistry, Faculty of Science, King Abdulaziz University, \\ North Jeddah, P.O Box 80203 Jeddah 21589, Saudi Arabia. \\ Department of Chemistry, Faculty of Science, King Saud University, \\ P.O.Box 2455 Riyadh - 11451, Saudi Arabia. \\ ${ }^{3}$ Biological Sciences Department, Faculty of Science, North Jeddah, King Abdulaziz \\ University, P.O. Box 80327, Jeddah 21454, Saudi Arabia. \\ *Corresponding author E-mail: chem_org@ hotmail.com \\ http://dx.doi.org/10.13005/ojc/300205 \\ (Received: March 02, 2014; Accepted: April 07, 2014)

\begin{abstract}
The currently available antimicrobial drugs suffer from toxicity, interactions with other drugs, insufficient pharmacokinetic properties, and the development of resistance. Thus, development of new antimicrobial agents with optimum pharmacokinetics and low toxicity is important. In this study, a series of flavanone, hydrazone derivatives have been prepared from flavanone under microwave irradiation after a very short reaction time (1-2 min.) with good yields. The structures of the synthesized compounds were elucidated using various spectroscopic methods. The screening of the synthesized compounds for antimicrobial activity was performed against Staphylococcus aureus, Escherichia coli, C. Albicans and Aspergillus niger. Some of the synthesized compounds show potent anti microbial activity.
\end{abstract}

Key words: Microwave irradiation, Flavanone, Hydrazone, Isoniazide, Antimicrobial activity.

\section{INTRODUCTION}

Flavanones, which exhibited broad spectrum of biological activities, have long attracted the interest of chemists. The most commonly reported biological activities include neuron protection, anti-tumor, anti-metastasis, anti- microbial, anti-oxidant, anti-inflammatory, and antiviral activities ${ }^{1-8}$. Flavanones, which have chemical structures embedded with a 2-aryl chroman-4-one skeleton, are widely distributed in plants ${ }^{9}$ and are available from synthetic sources. The major and most commonly reported synthetic methods for flavanones 4 usually involve the Claisen Schmidt 
reaction of o-hydroxyacetophenones 1 with benzaldehydes 2 to produce chalcone intermediates 3 using various catalysts ${ }^{10-14}$, followed

by cyclization with various bases ${ }^{15}$, acids ${ }^{16}$, or other materials (Scheme 1$)^{17}$.

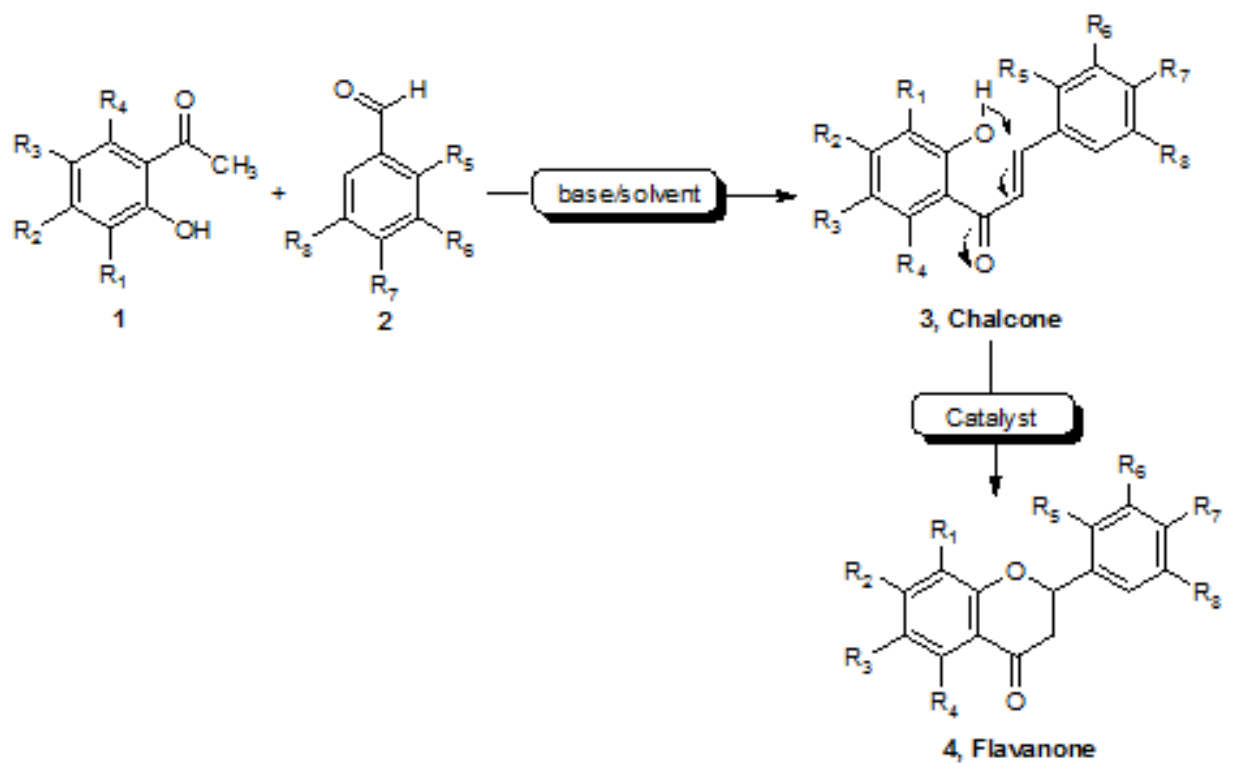

Scheme 1:

Recently, we reported the simple and high yield and no side products ${ }^{14}$ highlighting the efficient microwave-assisted synthesis of $2^{\prime}$ - role of different substituent in directing the reaction hydroxychalcones and flavanones in one step with to pure chalcone or flavanone product (Figure 1).

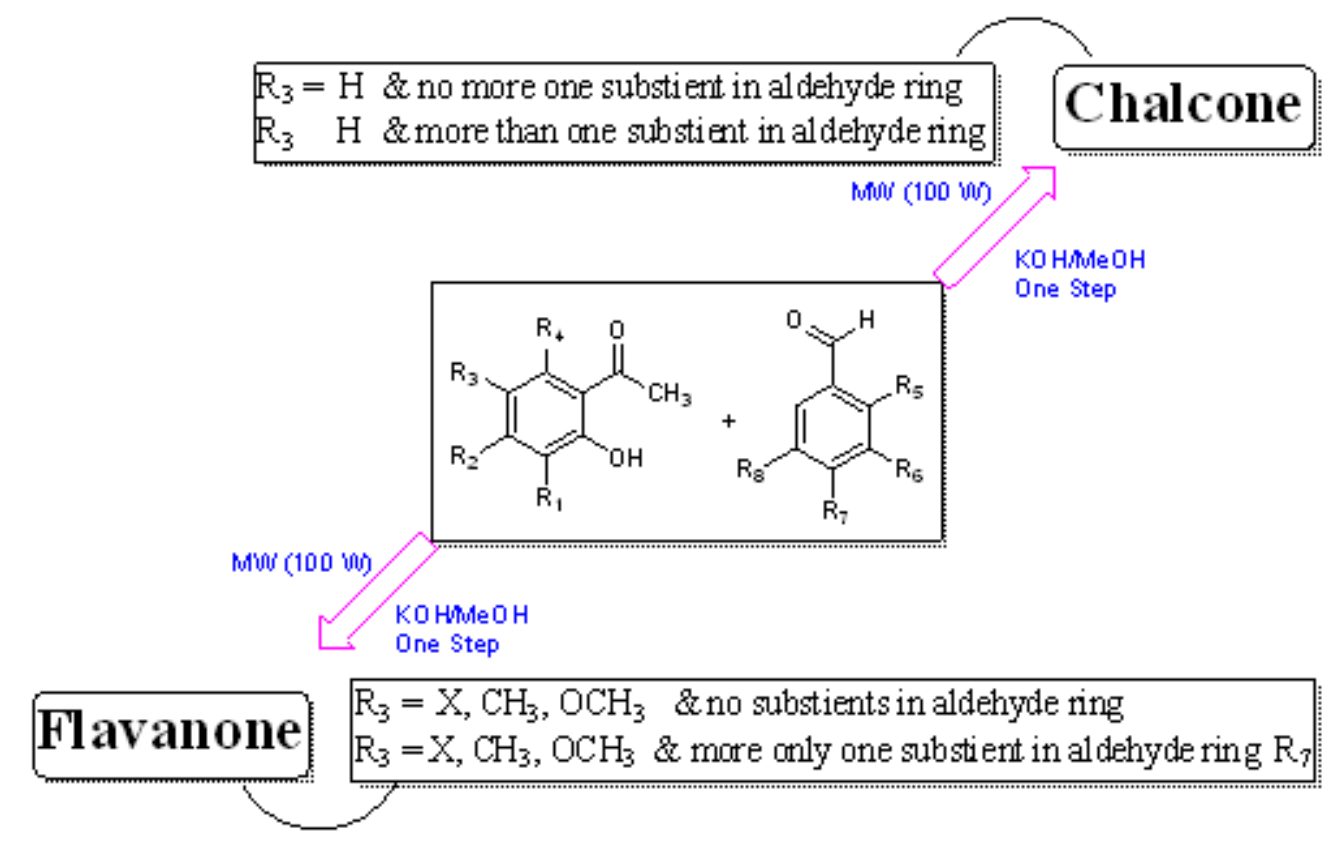

Fig. 1: Substitution effect in synthesis of flvanone 
The use of microwave irradiation in organic synthesis has become increasingly popular within the pharmaceutical and academic areas, as a new technology enabling drug discovery and development ${ }^{18,19}$. By taking advantage of this efficient source of energy (enhanced reaction rates, high yields, improved purity, ease of work up after the reaction and eco-friendly reaction conditions relative to conventional methods), compound libraries for lead generation and optimization can be assembled in a fraction of the time required by classical thermal methods.

Prompted by these observations and the importance of flavanones, we report the microwaveassisted synthesis of new flavanone derivatives and the evaluation of their antimicrobial activity.

\section{EXPERIMENTAL}

\section{Materials and methods}

All materials and reagents of the best available quality were purchased from commercial sources and used without further purification. Melting points are uncorrected and were determined on Gallenkamp-melting point apparatus. NMR spectra were recorded on JEOL ECP 400 (400 MHz) in $\mathrm{CDCl}_{3}$ and expressed as ' in ppm. Mass spectra were recorded on Shimadzu QP-5050A GC/MS system. Microwave experiments were carried out using CEM MARS synthator ${ }^{\mathrm{TM}}$ microwave apparatus. TLC was performed on (TLC plates silica gel $60 \mathrm{~F}_{245}$ pre-coated $20 \times 20 \mathrm{~cm}$ layer thickness $0.25 \mathrm{~mm}$ ). Elemental analyses were carried out on EuroVector instrument $\mathrm{C}, \mathrm{H}, \mathrm{N}, \mathrm{S}$ analyzer EA3000 Series. Microwave experiments were carried out using CEM MARS synthator ${ }^{\mathrm{TM}}$ microwave apparatus with temperature control for MW experiments using IR sensor. Flavanone 4a$\mathrm{d}^{14}$ was prepared according to the reported literature.

Typical procedure for synthesis of flavanone derivatives $5 \mathrm{a}-\mathrm{d}$ and $\mathbf{1 0 a - d}$

An equimolar amount of flavanone $4 a-d$ and phenyl hydrazine or isoniazide were mixed in a process vial in presence of $1 \mathrm{ml}$ acetic acid and irradiated with microwave (Power 300 watt) for 1-2 min (as examined by TLC), after reaction completion the precipitate was filtered and washed with ethanol and the products (81-92\% yield) were crystallized from ethanol. The synthesized compounds with their physical data are listed below.

\section{1-(6-Bromo-2-phenylchroman-4-ylidene)-2-} phenylhydrazine.

m.p. $112-114{ }^{\circ} \mathrm{C}$, yield $81 \%$; IR $(\mathrm{KBr})$ : $3327(\mathrm{NH})$, $1605(\mathrm{C}=\mathrm{N}), \mathrm{cm}^{-1} ;{ }^{1} \mathrm{H} \mathrm{NMR}\left(400 \mathrm{MHz}, \mathrm{CDCl}_{3}\right) \delta: 2.76$ (dd, $1 \mathrm{H}, \mathrm{J}=16.8,5.1 \mathrm{~Hz}, \mathrm{H}_{3 \mathrm{a}}$ ), 3.34 (dd, $1 \mathrm{H}, \mathrm{J}=2.9$, $16.8 \mathrm{~Hz}, \mathrm{H}_{3 \mathrm{~b}}$ ), 5.25 (dd, $1 \mathrm{H}, \mathrm{J}=2.9,11.7 \mathrm{~Hz}, \mathrm{H}_{2}$ ), 7.26-7.85 (m, 13H, Ar-H), $9.56\left(\mathrm{~s}, 1 \mathrm{H}, \mathrm{NH}, \mathrm{D}_{2} \mathrm{O}-\right.$ exchangeable), ${ }^{13} \mathrm{C} \mathrm{NMR}\left(100 \mathrm{MHz}, \mathrm{CDCl}_{3}\right) \delta: 39.9$, $77.2,112.5,114.9,116.6,121.7,124.3,127.0$, 127.6, 128.0, 128.8, 129.7, 134.1, 139.9, 143.1, 147.9, 155.1. MS (m/z): $392\left(\mathrm{M}^{+}\right)$. (Found: C, 64.38; $\mathrm{H}, 4.28$; N, $6.95 \mathrm{C}_{21} \mathrm{H}_{17} \mathrm{BrN}_{2} \mathrm{O}$ Calc. C, 64.13; $\mathrm{H}, 4.36$; $\mathrm{N}, 7.12 \%$ ).

1-(6-Chloro-2-phenylchroman-4-ylidene)-2phenylhydrazine. 5b

m.p. $194-195{ }^{\circ} \mathrm{C}$, yield $88 \%$; IR ( $\left.\mathrm{KBr}\right): 3323(\mathrm{NH})$, $1599(\mathrm{C}=\mathrm{N}), \mathrm{cm}^{-1} ;{ }^{1} \mathrm{H}$ NMR (400 MHz, $\left.\mathrm{CDCl}_{3}\right) \delta$ : 2.77 (dd, $\left.1 \mathrm{H}, \mathrm{J}=16.8,4.4 \mathrm{~Hz}, \mathrm{H}_{3 \mathrm{a}}\right), 3.36(\mathrm{dd}, 1 \mathrm{H}, \mathrm{J}$ $\left.=4.4,16.8 \mathrm{~Hz}, \mathrm{H}_{3 \mathrm{~b}}\right), 5.22(\mathrm{dd}, 1 \mathrm{H}, \mathrm{J}=2.2,11.7 \mathrm{~Hz}$, $\mathrm{H}_{2}$ ), 7.19-7.77 (m, 13H, Ar-H), 9.55 (s, 1H, NH, D $\mathrm{O}-$ exchangeable), ${ }^{13} \mathrm{C}$ NMR (100 MHz, $\mathrm{CDCl}_{3}$ ) $\delta: 39.7$, $77.2,112.1,114.2,119.8,121.00,125.1,126.1$, $127.5,128.0,128.9,129.9,134.0,139.5,143.0$, 145.2, 154.7. MS (m/z): $348\left(\mathrm{M}^{+}\right)$. (Found: C, 72.64; $\mathrm{H}, 4.78 ; \mathrm{N}, 7.83 ; \mathrm{C}_{21} \mathrm{H}_{17} \mathrm{CIN}_{2} \mathrm{O}$ Calc. C, 72.31; $\mathrm{H}, 4.91$; N, $8.03 \%$ ).

\section{1-(6-Methoxy-2-phenylchroman-4-ylidene)-2- phenylhydrazine. 5c}

m.p. $174{ }^{\circ} \mathrm{C}$, yield $81 \%$; IR (KBr): 3298 (NH), $1605(\mathrm{C}=\mathrm{N}), \mathrm{cm}^{-1} ;{ }^{1} \mathrm{H} \mathrm{NMR}\left(400 \mathrm{MHz}, \mathrm{CDCl}_{3}\right)$ $\delta: 2.72$ (dd, $\left.1 \mathrm{H}, \mathrm{J}=16.9,5.1 \mathrm{~Hz}, \mathrm{H}_{3 \mathrm{a}}\right), 3.33$ (dd, $1 \mathrm{H}$, $J=16.9,2.9 \mathrm{~Hz}, \mathrm{H}_{3 \mathrm{~b}}$ ), 3.83 (s, 3H, OMe), 5.16 (dd, $\left.1 \mathrm{H}, \mathrm{J}=2.9,11.7 \mathrm{~Hz}, \mathrm{H}_{2}\right), 7.21-7.88(\mathrm{~m}, 13 \mathrm{H}, \mathrm{Ar}-\mathrm{H})$, 9.42 (s, 1H, NH, D O-exchangeable), ${ }^{13} \mathrm{C}$ NMR (100 $\left.\mathrm{MHz} \mathrm{CDCl}_{3}\right)$ \&: 39.7, 50.1, 77.1, 112.3, 115.0, 116.5, 119.0, 121.6, 126.5, 127.8, 128.1, 129.4, 139.1, 143.0, 147.2, 148.9, 154.4. MS (m/z): $344\left(\mathrm{M}^{+}\right)$. (Found: C, 77.02; $\mathrm{H}, 5.73 ; \mathrm{N}, 7.95 ; \mathrm{C}_{22} \mathrm{H}_{20} \mathrm{~N}_{2} \mathrm{O}_{2}$ Calc. C, 76.72; H, 5.85; N, 8.13\%).

1-(2-(4-Chlorophenyl)-6-methoxychroman-4ylidene)-2-phenylhydrazine. 5d

m.p. $133-135^{\circ} \mathrm{C}$, yield $82 \%$; IR (KBr): $3322(\mathrm{NH})$, 
$1602(\mathrm{C}=\mathrm{N}), \mathrm{cm}^{-1} ;{ }^{1} \mathrm{H} \mathrm{NMR}\left(400 \mathrm{MHz}, \mathrm{CDCl}_{3}\right)^{\prime}: 2.71$ (dd, $1 \mathrm{H}, \mathrm{J}=16.8,4.5 \mathrm{~Hz}, \mathrm{H}_{3 \mathrm{a}}$ ), 3.35 (dd, $1 \mathrm{H}, \mathrm{J}=2.9$, $17.6 \mathrm{~Hz}, \mathrm{H}_{3 \mathrm{~b}}$ ), 3.81 (s, 3H, OMe), 5.20 (dd, 1H, J = 2.9, $11.8 \mathrm{~Hz}, \mathrm{H}_{2}$ ), 7.20-7.78 (m, 12H, Ar-H), 9.44 (s, $1 \mathrm{H}, \mathrm{NH}, \mathrm{D}_{2} \mathrm{O}$-exchangeable), ${ }^{13} \mathrm{C}$ NMR $(100 \mathrm{MHz}$, $\left.\mathrm{CDCl}_{3}\right)$ \&: 39.9, 51.0, 76.3, 112.2, 114.9, 116.5, 119.1, 121.0, 126.2, 129.0, 129.9, 134.0, 136.6, 143.2, 147.2, 149.5, 154.5. MS (m/z): $378\left(\mathrm{M}^{+}\right)$. (Found: C, 70.08; H, 4.92; N, 7.19; $\mathrm{C}_{22} \mathrm{H}_{19} \mathrm{CIN}_{2} \mathrm{O}_{2}$ Calc. C, 69.75; $\mathrm{H}, 5.05 ; \mathrm{N}, 7.39 \%)$.

4-(2-(6-bromo-2-phenylchroman-4-ylidene) hydrazinyl)pyridine. $10 \mathrm{a}$

m.p. 200-202 ${ }^{\circ} \mathrm{C}$, yield 84\%; IR (KBr): 3365 $(\mathrm{NH}), 1690(\mathrm{C}=\mathrm{O}), 1598(\mathrm{C}=\mathrm{N}), \mathrm{cm}^{-1} ;{ }^{1} \mathrm{H}$ NMR (400 $\mathrm{MHz}, \mathrm{DMSO}) \delta: 2.77$ (dd, $1 \mathrm{H}, \mathrm{J}=17.6,5.1 \mathrm{~Hz}, \mathrm{H}_{3 \mathrm{a}}$ ), 3.38 (dd, $1 \mathrm{H}, \mathrm{J}=16.8,2.9 \mathrm{~Hz}, \mathrm{H}_{3 \mathrm{~b}}$ ), 5.25 (dd, $1 \mathrm{H}, \mathrm{J}=$ 2.9, $\left.11.7 \mathrm{~Hz}, \mathrm{H}_{2}\right), 6.92-7.88(\mathrm{~m}, 12 \mathrm{H}, \mathrm{Ar}-\mathrm{H}$ and Pyridine-H), 9.56 (s, $1 \mathrm{H}, \mathrm{NH}, \mathrm{D}_{2} \mathrm{O}$-exchangeable), ${ }^{13} \mathrm{C}$ NMR (100 MHz, DMSO) $\delta: 39.6,77.2,113.4$, $114.1,114.8,119.5,122.7,126.5,127.6,128.0$, 133.0, 134.0, 139.1, 140.1, 145.9, 154.6, 160.2. MS $(\mathrm{m} / \mathrm{z})$ : $421\left(\mathrm{M}^{+}\right)$. (Found: C, 60.03; H, 3.69; N, 9.78; $\mathrm{C}_{21} \mathrm{H}_{16} \mathrm{BrN}_{3} \mathrm{O}_{2}$ Calc. C, 59.73; H, 3.82; N, 9.95\%).

\section{4-(2-(6-chloro-2-phenylchroman-4-ylidene) hydrazinyl)pyridine. 10b}

m.p. $194-195^{\circ} \mathrm{C}$, yield 92\%; IR (KBr): 3359 $(\mathrm{NH}), 1697(\mathrm{C}=\mathrm{O}), 1605(\mathrm{C}=\mathrm{N}), \mathrm{cm}^{-1} ;{ }^{1} \mathrm{H}$ NMR (400 $\left.\mathrm{MHz} \mathrm{CDCl}_{3}\right) \delta: 2.75\left(\mathrm{dd}, 1 \mathrm{H}, \mathrm{J}=16.8,5.1 \mathrm{~Hz}, \mathrm{H}_{3 \mathrm{a}}\right)$, 3.39 (dd, $\left.1 \mathrm{H}, \mathrm{J}=17.6,4.4 \mathrm{~Hz}, \mathrm{H}_{3 \mathrm{~b}}\right), 5.29$ (dd, $1 \mathrm{H}, \mathrm{J}=$ 2.9, $\left.12.4 \mathrm{~Hz}, \mathrm{H}_{2}\right)$, 6.89-7.91 (m, 12H, Ar-H and Pyridine-H), 9.56 (s, 1H, NH, D $\mathrm{O}$-exchangeable), ${ }^{13} \mathrm{C}$ NMR $\left(100 \mathrm{MHz} \mathrm{CDCl}_{3}\right) \delta: 39.6,77.2,113.5$, $114.0,117.1,122.9,126.0,127.6,127.9,128.5$, 128.7, 132.0, 138.2, 139.9, 145.9, 154.6, 159.2. MS (m/z): $377\left(\mathrm{M}^{+}\right)$. (Found: C, 66.99; H, 4.18; N, 10.98; $\mathrm{C}_{21} \mathrm{H}_{16} \mathrm{CIN}_{3} \mathrm{O}_{2}$ Calc. C, 66.76; H, 4.27; N, 11.12\%).

\section{4 - ( 2 - ( 6 - Methoxy - 2 - phen y lch roman - 4 -} ylidene)hydrazinyl)pyridine. 10c

m.p. $144-145^{\circ} \mathrm{C}$, yield $88 \%$; IR (KBr): 3361 $(\mathrm{NH}), 1691(\mathrm{C}=\mathrm{O}), 1601(\mathrm{C}=\mathrm{N}), \mathrm{cm}^{-1} ;{ }^{1} \mathrm{H}$ NMR (400 $\mathrm{MHz} \mathrm{CDCl}_{3}$ ) $\delta: 2.73\left(\mathrm{dd}, 1 \mathrm{H}, \mathrm{J}=16.8,4.4 \mathrm{~Hz}, \mathrm{H}_{3 \mathrm{a}}\right.$ ), $3.36\left(\mathrm{dd}, 1 \mathrm{H}, \mathrm{J}=2.9,16.8 \mathrm{~Hz}, \mathrm{H}_{3 \mathrm{~b}}\right.$ ), 3.77 (s, 3H, $\mathrm{OMe}$ ), 5.18 (dd, $1 \mathrm{H}, \mathrm{J}=2.9,11.7 \mathrm{~Hz}, \mathrm{H}_{2}$ ), 7.01-7.84 (m, 12H, Ar-H), 9.45 (s, 1H, NH, D O-exchangeable), ${ }^{13} \mathrm{C} \mathrm{NMR}\left(100 \mathrm{MHz} \mathrm{CDCl}_{3}\right) \delta: 39.8,50.8,77.1,112.2$, $114.7,116.2$, 117.0, 117.3, 121.9, 126.9, 127.1,
128.0, 138.0, 139.6, 147.1, 150.4, 154.4, 160.0. MS $(\mathrm{m} / \mathrm{z})$ : $373\left(\mathrm{M}^{+}\right)$. (Found: C, 70.98; H, 5.07; N, 11.09; $\mathrm{C}_{22} \mathrm{H}_{19} \mathrm{~N}_{3} \mathrm{O}_{3}$ Calc. C, 70.76; H, 5.13; N, 11.25\%).

4-(2-(2-(4-chlorophenyl)-6-methoxychroman-4ylidene)hydrazinyl)pyridine. 10d

m.p. $124-126^{\circ} \mathrm{C}$, yield 86\%; IR (KBr): 3359 $(\mathrm{NH}), 1690(\mathrm{C}=\mathrm{O}), 1602(\mathrm{C}=\mathrm{N}), \mathrm{cm}^{-1}$; ${ }^{1} \mathrm{H}$ NMR (400 $\left.\mathrm{MHz} \mathrm{CDCl}_{3}\right) \delta: 2.71\left(\mathrm{dd}, 1 \mathrm{H}, \mathrm{J}=16.8,4.4 \mathrm{~Hz}, \mathrm{H}_{3 \mathrm{a}}\right)$, $3.36\left(\mathrm{dd}, 1 \mathrm{H}, \mathrm{J}=2.9,16.8 \mathrm{~Hz}, \mathrm{H}_{3 \mathrm{~b}}\right.$ ), 3.71 (s, 3H, OMe), $5.20\left(\mathrm{dd}, 1 \mathrm{H}, \mathrm{J}=2.9,12.4 \mathrm{~Hz}, \mathrm{H}_{2}\right), 6.89-7.92(\mathrm{~m}$, $11 \mathrm{H}, \mathrm{Ar}-\mathrm{H}), 9.45$ (s, $1 \mathrm{H}, \mathrm{NH}, \mathrm{D}_{2} \mathrm{O}$-exchangeable), ${ }^{13} \mathrm{C} \mathrm{NMR}\left(100 \mathrm{MHz} \mathrm{CDCl}_{3}\right) \delta: 39.4,51.0,76.3,112.8$, $114.0,116.1,117.2,117.9,122.0,126.2,128.7$, 134.1, 135.2, 139.7, 146.8, 150.2, 154.5, 160.0.MS (m/z): $407\left(\mathrm{M}^{+}\right)$. (Found: C, 65.07; H, 4.33; N, 10.14. $\mathrm{C}_{22} \mathrm{H}_{18} \mathrm{CIN}_{3} \mathrm{O}_{3}$ Calc. C, 64.79; H, 4.45; N, $10.30 \%$ ).

\section{Antimicrobial activity}

The antimicrobial activity was investigated on the newly green synthesized Hydrazon, Flavanone and Iso-niazide compounds. The antimicrobial profile was evaluated by measuring the inhibitory effects and the potency of such compounds against Gram positive, Gram negative bacteria and fungi using the agar diffusion technique 29 .

The bacterial strains Escherichia coli ( $E$. coli) and Staphylococcus aureus (S. aureus) were cultured on nutrient agar. The fungal strains Candida albicans (C. albicans) was maintained on Yeast malt extracts medium (YM), while Aspergillus niger ( $A$. niger) was maintained on Czapeck Dox medium. All the four strains were used against the tested compounds for antimicrobial evaluation.

Suspension of the above mentioned bacterial strains was prepared by inoculating fresh stock cultures into separate broth tubes, each containing $7 \mathrm{ml}$ of nutrient broth. The inoculated tubes were incubated at $27 \pm 2^{\circ} \mathrm{C}$ for $24 \mathrm{~h}$.

Solutions of the tested compounds and reference drugs were prepared by dissolving $0.5 \mathrm{~g}$ of the compound in chloroform $(5 \mathrm{ml})$.

\section{RESULTS AND DISCUSSION}

As the condensation reactions of amines and hydrazines with ketones are usually catalysed 
by acids or bases, the synthetic route to phenylhydrazone derivatives $5 a-d$ is illustrated in Scheme 2. The starting flavanone derivatives $4 a-d$ were prepared from the corresponding 2'hydroxyacetophenones according to the literature method $^{14}$. The synthesis of phenylhydrazone derivatives $5 a-d$ was attempted by the reaction of flavanone $4 a-d$ with phenylhydrazine under microwave irradiation in the presence of $1 \mathrm{ml}$ of acetic acid, which resulted in good to excellent yield of pure phenylhydrazone products in very short reaction times (1-2 $\mathrm{min}$.). The synthetic route to phenylhydrazone derivatives $5 a-d$ is illustrated in Scheme 2.

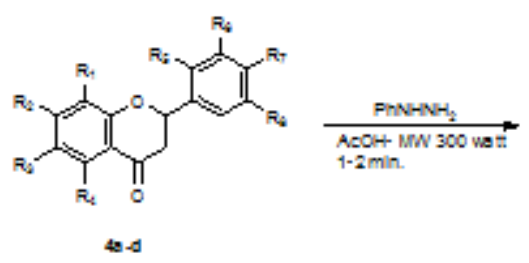

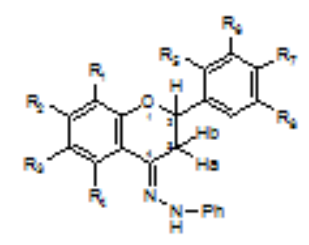

6as

$\begin{array}{lllllllll}\mathbf{4 , 5} & \mathbf{R}_{1} & \mathbf{R}_{\mathbf{2}} & \mathbf{R}_{\mathbf{3}} & \mathbf{R}_{\mathbf{4}} & \mathbf{R}_{\mathbf{5}} & \mathbf{R}_{6} & \mathbf{R}_{\mathbf{7}} & \mathbf{R}_{\mathbf{8}} \\ & & & & & & & & \\ \text { A } & \text { H } & \text { H } & \text { Br } & \text { H } & \text { H } & \text { H } & \text { H } & \text { H } \\ \text { B } & \text { H } & \text { H } & \text { Cl } & \text { H } & \text { H } & \text { H } & \text { H } & \text { H } \\ \text { C } & \text { H } & \text { H } & \text { OMe } & \text { H } & \text { H } & \text { H } & \text { H } & \text { H } \\ \text { D } & \text { H } & \text { H } & \text { OMe } & \text { H } & \text { H } & \text { H } & \text { Cl } & \text { H }\end{array}$

\section{Scheme 2: synthesis of flavanone hydrazone derivatives 5a-d}

Theoretically, the reactivity of flavanone derivatives toward $\mathrm{N}$-nucleophiles, such as substituted hydrazine, is related to two sites: the carbonyl group and C-2 position. The attack of hydrazine to the $\mathrm{C}-2$ position of a chroman ring could result in ring opening and subsequent pyrazoline formation. Previously, the reaction of flavanone derivatives with substituted hydrazines has been investigated under different conditions ${ }^{20.21}$. Kállay et al. have reported that flavanone

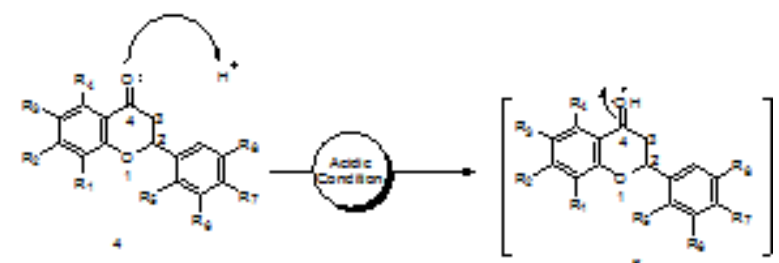

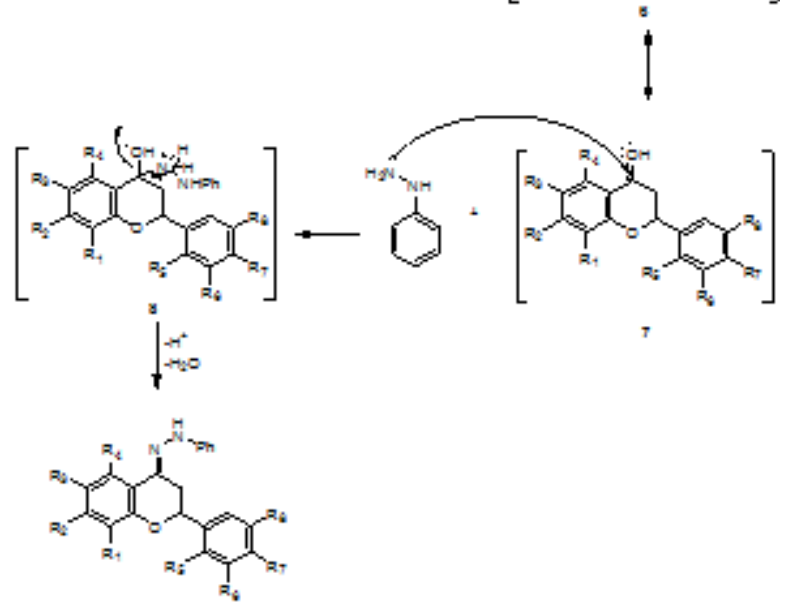

Scheme 3: Proposed mechanism for formation of flavanone hydrazone derivatives. 
hydrazones are predominantly obtained under acidic conditions while alkaline conditions give the pyrazolines and the 2-hydroxychalcone derivatives due to the ring cleavage of the hetero ring of chromanone ${ }^{20}$. Similarly, in our experiment with flavanone 4a-d, the hydrazone derivatives were predominantly obtained under mild acidic conditions, Scheme 3.

The structures of compounds $5 \mathrm{a}-\mathrm{d}$ were characterized by IR, ${ }^{1} \mathrm{H}$ NMR and mass spectroscopy as well as elemental analysis. For example, the IR spectra of compound $5 \mathrm{a}$ did not show any absorption due to the presence of $\mathrm{C}=\mathrm{O}$ groups, and a broad band was observed at 3298$3327 \mathrm{~cm}^{-1}$ due to the presence of a N"H bond. The ${ }^{1} \mathrm{H}$ NMR spectrum of $5 \mathrm{a}$ showed a singlet $\mathrm{D}_{2} \mathrm{O}$ exchangeable signal at $\mathrm{d} 9.56$ for $\mathrm{NH}$; three doublets of doublet signals at d $2.76(\mathrm{~J}=16.84,5.12 \mathrm{~Hz})$, $3.34(\mathrm{~J}=2.92,16.84 \mathrm{~Hz})$ and $5.25(\mathrm{~J}=2.96,11.76$ $\mathrm{Hz}$ ) for $\mathrm{H}-3 \mathrm{a}, \mathrm{H}-3 \mathrm{~b}$ and $\mathrm{H}-2$ of the chroman ring, respectively; and a multiplet of aromatic protons at d 7.26-7.85 ppm.

In a similar manner, the isoniazid (isonicotinylhydrazine) (9) reacted with flavanone derivatives $10 \mathrm{a}-\mathrm{d}$ under microwave irradiation to give the corresponding hydrazone derivatives, Scheme 4.

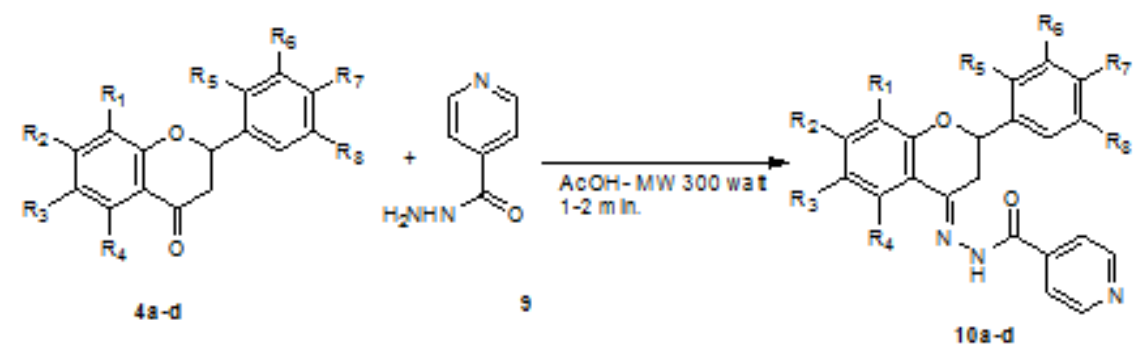

$\begin{array}{lllllllll}4,10 & \mathrm{R}_{1} & \mathrm{R}_{2} & \mathrm{R}_{3} & \mathrm{R}_{4} & \mathrm{R}_{5} & \mathrm{R}_{6} & \mathrm{R}_{7} & \mathrm{R}_{8} \\ \mathrm{~A} & \mathrm{H} & \mathrm{H} & \mathrm{Br} & \mathrm{H} & \mathrm{H} & \mathrm{H} & \mathrm{H} & \mathrm{H} \\ \mathrm{B} & \mathrm{H} & \mathrm{H} & \mathrm{Cl} & \mathrm{H} & \mathrm{H} & \mathrm{H} & \mathrm{H} & \mathrm{H} \\ \mathrm{C} & \mathrm{H} & \mathrm{H} & \mathrm{OMe} & \mathrm{H} & \mathrm{H} & \mathrm{H} & \mathrm{H} & \mathrm{H} \\ \mathrm{D} & \mathrm{H} & \mathrm{H} & \mathrm{OMe} & \mathrm{H} & \mathrm{H} & \mathrm{H} & \mathrm{Cl} & \mathrm{H}\end{array}$

\section{Scheme 4: Synthesis of flavanone hydrazone derivatives 10a-d}

The structure of flavanone derivatives 10a$\mathrm{d}$ was assigned based on their elemental analyses and spectral data. For example, the ${ }^{1} \mathrm{H}$ NMR spectrum of compound 10 a revealed a singlet $\mathrm{D}_{2} \mathrm{O}$ exchangeable signal at $\mathrm{d} 9.56$ for $\mathrm{NH}$; three doublets of doublet signals at d $2.77(\mathrm{~J}=17.60,5.16 \mathrm{~Hz})$, $3.38(\mathrm{~J}=2.92,16.84 \mathrm{~Hz})$ and $5.25(\mathrm{~J}=2.96,11.76$ $\mathrm{Hz}$ ) for $\mathrm{H}-3 \mathrm{a}, \mathrm{H}-3 \mathrm{~b}$ and $\mathrm{H}-2$ of the chroman ring, respectively; and a multiplet of aromatic protons at d 6.92-7.88 ppm. The mass spectrum of the same compound revealed a peak corresponding to its molecular ion at $\mathrm{m} / \mathrm{z} 421$.

It was found that microwave irradiation has a beneficial effect on the synthesis of flavanone derivatives. The above reactions took less than 5 min., and provided excellent yields.

\section{Antimicrobial activity}

The results in table 1 showed that flavanone compounds were the most potent among the three classes (flavanone, hydrazone and isoniazide) in terms of antibacterial activity. The highest inhibition zone against $E$. coli was detected by flavanone compound $4 \mathrm{a}$ followed by $4 \mathrm{c}$, while, $4 d$ was the most potent flavanone compound against $S$. aureus. Compounds $5 d, 5 c$ and $5 b$ of hydrazone were the most potent and exhibited the highest inhibition zone against $E$. coli while, $5 \mathrm{~b}$ was the most potent compound against $S$. aureus. The isoniazide $10 \mathrm{c}$ and $10 \mathrm{~b}$ were the most potent compounds against $E$. coli and the $10 \mathrm{~b}$ isoniazide was the most potent compound against $S$. aureus.

The results in table 2 revealed that hydrazone compounds were the most potent among 
Table 1: Antibacterial activity of test compounds and reference druga

\begin{tabular}{|c|c|c|c|c|}
\hline \multirow[t]{3}{*}{ Compounds } & \multicolumn{4}{|c|}{ Inhibition zone diameter (mm) } \\
\hline & \multicolumn{2}{|c|}{ G-ve } & \multicolumn{2}{|c|}{ G+ve } \\
\hline & E. coli & Potency & S. aureus & Potency \\
\hline Control & $0.0 \pm 0.0$ & 0.0 & $0.0 \pm 0.0$ & 0.0 \\
\hline $\begin{array}{l}\text { Standard } \\
\text { Flavanone }\end{array}$ & $12.0 \pm 0.2$ & 1.0 & $13.0 \pm 0.5$ & 1.0 \\
\hline $4 a$ & $19.0 \pm 1.4$ & 1.6 & $16.0 \pm 1.4$ & 1.2 \\
\hline $4 b$ & $16.0 \pm 1.4$ & 1.3 & $14.5 \pm 0.7$ & 1.1 \\
\hline $4 c$ & $17.5 \pm 0.7$ & 1.5 & $16.0 \pm 0.0$ & 1.2 \\
\hline $\begin{array}{l}\text { 4d } \\
\text { Hydrazone }\end{array}$ & $17.0 \pm 0.0$ & 1.4 & $16.5 \pm 0.7$ & 1.3 \\
\hline $5 a$ & $12.5 \pm 0.7$ & 1.04 & $0.0 \pm 0.0$ & 0.0 \\
\hline $5 b$ & $16.5 \pm 0.7$ & 1.4 & $20.0 \pm 0.0$ & 1.5 \\
\hline $5 c$ & $18.0 \pm 0.0$ & 1.5 & $11.0 \pm 0.0$ & 0.8 \\
\hline $\begin{array}{l}5 d \\
\text { Isoniazide }\end{array}$ & $21.5 \pm 0.7$ & 1.8 & $15.5 \pm 0.7$ & 1.2 \\
\hline $10 a$ & $14.0 \pm 1.4$ & 1.2 & $12.0 \pm 0.0$ & 0.9 \\
\hline $10 b$ & $16.0 \pm 1.4$ & 1.3 & $14.0 \pm 1.4$ & 1.1 \\
\hline $10 c$ & $17.0 \pm 0.0$ & 1.4 & $11.0 \pm 0.0$ & 0.8 \\
\hline $10 d$ & $13.5 \pm 2.1$ & 1.1 & $0.0 \pm 0.0$ & 0.0 \\
\hline
\end{tabular}

${ }^{a}$ Chloroform has no antibacterial activity at the concentration used to dissolve the test compounds.

b Standard for bacteria: chloramphenicol.

Table 2: Antibacterial activity of test compounds and reference drug ${ }^{a}$

\begin{tabular}{lllll}
\hline \multirow{2}{*}{ Compounds } & \multicolumn{3}{c}{ Inhibition zone diameter $(\mathrm{mm})$} \\
\cline { 2 - 3 } & \multicolumn{3}{c}{ Yeast } & \multicolumn{2}{c}{ Mould } \\
\cline { 2 - 3 } \cline { 5 - 5 } & C. albicans & Potency & A. niger & Potency \\
\hline Control & $0.0 \pm 0.0$ & 0.00 & $0.0 \pm 0.0$ & 0.00 \\
Standard & $15.5 \pm 1.2$ & 1.00 & $14.0 \pm 1.4$ & 1.00 \\
Flavanone & & & & \\
4a & $13.5 \pm 2.1$ & 0.9 & $12.0 \pm 0.0$ & 0.9 \\
4b & $0.0 \pm 0.0$ & 0.0 & $0.0 \pm 0.0$ & 0.0 \\
4c & $0.0 \pm 0.0$ & 0.0 & $0.0 \pm 0.0$ & 0.0 \\
4d & $0.0 \pm 0.0$ & 0.0 & $0.0 \pm 0.0$ & 0.0 \\
Hydrazone & & & & \\
5a & $0.0 \pm 0.0$ & 0.0 & $0.0 \pm 0.0$ & 0.0 \\
5b & $20.0 \pm 0.0$ & 1.3 & $14.5 \pm 2.1$ & 1.0 \\
5c & $17.5 \pm 0.0$ & 1.1 & $20.0 \pm 0.0$ & 1.4 \\
5d & $20.0 \pm 0.0$ & 1.3 & $20.0 \pm 0.0$ & 1.4 \\
& Isoniazide & & & \\
10a & $34.0 \pm 1.4$ & 2.2 & $14.0 \pm 0.0$ & 1.0 \\
10b & $23.5 \pm 2.1$ & 1.5 & $14.0 \pm 2.8$ & 1.0 \\
10c & $15.5 \pm 0.7$ & 1.0 & $0.0 \pm 0.0$ & 0.0 \\
10d & $0.0 \pm 0.0$ & 0.0 & $0.0 \pm 0.0$ & 0.0 \\
\hline
\end{tabular}

a Chloroform has no antibacterial activity at the concentration used to dissolve the test compounds.

b Standard for bacteria: chloramphenicol. 
the three classes (flavanone, hydrazone and isoniazide) in terms of antifungal activity. None of the flavanone compounds exhibited potency against $C$. albicans and $A$. niger. Compounds $5 b$ and $5 \mathrm{~d}$ of hydrazone were the most potent and exhibited high inhibition zone against $C$. albicans whereas $5 c$ and $5 d$ were the most potent against $A$. niger. Isoniazide $10 \mathrm{a}$ and $10 \mathrm{~b}$ compounds were the most potent compounds against $C$. albicans and none of the isoniazide compounds had any effect against $A$. niger.

Several recent reviews and studies have reported the antimicrobial efficacy of flavanone molecules $^{22-24}$. The antimicrobial effectiveness of flavonoids is due to their abilities to form complexes with both extracellular and soluble proteins as well as bacterial membranes ${ }^{25,26}$. The penetration into the cell and the maintenance of intracellular concentrations in infecting species becomes a critical concern for the development of flavonoids as the next generation of antibacterial/antifungal agents.

Hydrazone-type compounds containing azomethine constitute an important class of compounds for new drug development. It is well known that the hydrazone group plays an important role in antimicrobial activity ${ }^{27}$. It has been claimed that a number of hydrazide-hydrazone derivatives possess interesting antibacterial and antifungal activities $^{28}$.

\section{CONCLUSIONS}

A series of flavanone hydrazone derivatives have been prepared from flavanone under microwave irradiation in very short reaction time (1-2 min.) and good yields. Some synthesized compounds show potent anti-microbial activity.

\section{REFERENCES}

1. Vauzour, D.; Vafeiadou, K.; Rice-Evans, C.; Williams, R. J.; Spencer, J. P. E. J. Neurochem. 2007, 103, 1355-1367.

2. Agarwal, C.; Tyagi, A.; Kaur, M.; Agarwal, R. Carcinogenesis 2007, 28, 1463-1470.

3. Cabrera, M.; Simoens, M.; Falchi, G.; Lavaggi, M. L.; Piro, O. E.; Castellano, E. E.; Vidal, A.; Azqueta, A.; Monge, A.; Lopez de Cerain, A.; Sagrera, G.; Seoane, G.; Cerecetto, H.; Gonzalez. M. Bioorg. Med. Chem. 2007, 15, 3356-3367.

4. Hsiao, Y. C.; Kuo, W. H.; Chen, P. N.; Chang, H. R.; Lin, T.H.; Yang, W. E.; Hsieh, Y. S.; Chu, S. C. Chem.-Biol. Interact. 2007, 167, 193-206.

5. Ward, F. E.; Garling, D. L.; Buckler, R. T.; Lawler, D. M.; Cummings, D. P. J. Med. Chem. 1981, 24, 1073-1077.

6. Choi, Y. J.; Lee, M. K.; Lee, Y. J.; Jeong, Y. J.; Yoon Park, J. H.; Sung, L. S.; Kang, Y. H. J. Med. Food 2004, 7, 408-416.

7. Njamen, D.; Mbafor, J. T.; Fomum, Z. T.; Kamanyi, A.; Mbanya, J. C.; Recio, M. C.; Giner, R. M.; Manez, S. J.; Rios, L. Planta Med. 2004, 70, 104-107.

8. Paredes, A.; Alzuru, M.; Mendez, J. Biol.
Pharm. Bull. 2003, 26, 108-109.

9. Reddy, M. V. B.; Kishore, P. H.; Rao, C. V.; Gunasekar, D.; Caux, C.; Bodo, B. J. Nat. Prod. 2003, 66, 295-297.

10. Wang, X.; Cheng, S. Catal. Commun. 2006, 7, 689-695.

11. Drexler, M. T.; Amiridis, M. D. J. Catal. 2003, 214, 136-145.

12. Chandrasekhar, S.; Vijeender, K.; Reddy, K. V. Tetrahedron Lett. 2005, 46, 6991-6993.

13. Choudary, B. M.; Ranganath, K. V. S.; Yadav, J.; Kantam, M. L. Tetrahedron Lett. 2005, 46, 1369-1371.

14. Albogami, A. S.; Karama, U.; Mousa, A. A.; Khan, M. S.; Al-Mazroa, A.; Alkhathlan, H. Z. Oriental J. Chem. 28: 619-626 (2012).

15. Coetzee, J.; Mciteka, L.; Malan, E.; Ferreira, D. Phytochemistry 1999, 52, 737-743.

16. Adams, J. H. J. Org. Chem. 1967, 32, 39923998.

17. Climent, M. J.; Garcia, H.; Iborra, S.; Miranda, M. A.; Primo, J. Heterocycles 1989, 29, 115121.

18. Lidstrom, P.; Tierney, J.; Wathcy, B.; Wcstman, J.; Tetrahedron 2001, 57, 9225-9283. 
19. Stadler, A.; Yousefi, B. H.; Dallinger, D.; Walla, P.; der Eycken, E. V.; Kaval, N.; Kappe, C. O. Org. Proc. Res. Dev. 2003, 7, 707-716.

20. Kállay, F.; Janzsó, G.; Koczor, I. Tetrahedron 1967, 23, 4317-4321.

21. Léavai, A. J. Heterocycl. Chem. 2002, 39, 113.

22. Sobolev, V. S.; Neff, S. A.; Gloer, J. B. J. Agric. Food Chem., 2009, 57, 62-68.

23. Abdel Ghani, S. B.; Weaver, L.; Zidan, Z. H.; Ali, H. M. W.; Keevil, C. Bioorg Med Chem Lett., 2008, 18, 518-522.
24. Nowakowska, Z. Eur. J. Med. Chem. 2007, 42, 125-137.

25. Cowan, M. M. Clin. Microbiol. Rev. 1999, 12, 564-582.

26. Fowler, Z. L.; Baron, C. M.; Panepinto, J. C.; Koffas, M. A. Yeast 2011, 28, 181-188.

27. Abdel-Fattah, M. E.; Salem, E. E.; Mahmoud, M. A. Indian J. Heterocycl. Chem. 2000, 10, 121-128.

28. Vicini, P.; Zani, F.; Cozzini, P.; Doytchinova, I. Eur. J. Med. Chem. 2000, 37, 553-564. 